\title{
Investigating the effect of different factors on profitability
}

\author{
Mohsen Hamidiana and Shohreh Asghari Gildeh ${ }^{\mathrm{b}}$
}

${ }^{a}$ Assist. Prof. \& Faculty Member, Department of Management and Accounting, South Tehran Branch, Islamic Azad University (IAU), Tehran, Iran ${ }^{b}$ M.Sc. Student, Department of Management and Accounting, South Tehran Branch, Islamic Azad University (IAU), Tehran, Iran

\section{H R O N I C L E}

Article history:

Received June 4, 2014

Accepted 12 October 2014

Available online

October 282014

Petrochemical industry

Profitability

Tehran Stock Exchange \section{A B S T R A C T}

This paper presents an empirical investigation to study the effects of different factors influencing on profitability of shares of petrochemical industry. The study gathers the information of three firms whose stock prices were listed on Tehran Stock Exchange over the period 2006-2012. Using different regression analysis, the study has determined that while stock price, currency rate and material influence on profitability of these firms, energy price, liquidity and gold price had no impact on profitability in petrochemical industry.

C 2014 Growing Science Ltd. All rights reserved.

\section{Introduction}

During the past few years, there have been several studies on learning more about the effects of various factors on profitability of organizations (Patell, 1976; Feeny, 2000; Bernotas, 2005; Tursoy et al., 2008). Petrochemical is one of the most popular industries among investors in Tehran Stock Exchange. This industry depends mainly of the price of raw materials, which are under Iranian government control. The industry also depends on energy prices. Shaverdi et al. (2014) studied Iranian petrochemical industry and then proposed a framework for a good decision making model by looking into financial evaluation criteria. They considered current ratio, quick ratio, debt ratio, long term debt, EBIT, total asset, inventory turnover ratio, total asset turnover ratio, fixed asset turnover ratio, receivable accounting turnover ratio, net profit margin, ROI, ROE, asset growth, shareholder's equity growth as the financial criteria. They used fuzzy set and fuzzy analytical hierarchy process (AHP) (Saaty, 1990, 1994, 2003) to measure the effects of various factors. Stern (1974) is among the first pioneers who stated that earnings per share along could not present the performance of the firms. Khaksarian (2014) presented a study on the effect of working capital management on profitability on Cement and Petrochemical industries by looking into the information of firms listed on Tehran Stock Exchange. The study applied the information of 24 firms from Cement industry and 19 firms from Petrochemical industry. In their study, there were two independent variables including the ratio of

*Corresponding author.

E-mail addresses: shohre_0067@yahoo.com (S. Asghari Gildeh) 
current assets on total assets as well as the ratio of current liabilities on total assets in this survey. In addition, there were two dependent variables including return on assets (ROA) and Tobin's Q. The study also considered firm size, sales' growth, financial leverage, gross domestic product growth as control variables. Using stepwise regression technique, the study confirmed a positive and meaningful relationship between working capital criteria and profitability. Moreover, the study confirmed that as the ratio of current assets to total assets increased, ROA and Tobin's Q would be reduced, which means lower profitability would be resulted. Besides, as financial leverage increases, ROA in both industries will reduce while Tobin's Q will increase in Cement industry and will reduce in Petrochemical industry. Ghodrati et al. (2014) performed a study on relationship between assets' objectivity, ROA, ROE and ownership ratio with liquidity cycle (CCC). They confirmed a meaningful relationship between various variables and reported that CCC and size negatively influenced on tangible assets, they positively influence on equity multiplier as well as ROA but the effects of CCC and size on ROE for small and big firms were mixed.

Azad and Mohajeri (2002) investigated the effects of intellectual capital on financial performance in a case study of petrochemical and pharmaceutical firms in Iran. They we first calculated intellectual capital based on the ratio of market value/book value for three years period and then they investigated the relationship between intellectual capital and growth rate of intellectual capital as well as financial performance of some publicly traded petrochemical and pharmaceutical companies. Their results of our survey indicated that there was a positive relationship between intellectual capital and equity growth with EVA and return of assets. However, there was no meaningful relationship between intellectual assets with net earnings. Farzinfar (2012) studied the relationship between intellectual capital, earning per share and income growth: A case study of Tehran Stock Exchange.

Dechow (1994) investigated circumstances under which accruals were predicted to improve earnings' ability to compute firm performance, as reflected in stock returns. Madsen (2002) compared and examined the four different proxy hypotheses and investigated their ability to describe two empirical regularities, namely that the inflation elasticity of share returns tends towards zero in the postwar period and towards two in the interwar period. They reported that the proxy models could provide important insight into the relationship between inflation and share returns. Muller and Verschoor (2007) reported that about 25 percent of Asian firms experienced economically substantial exposure impacts to the US dollar and 22.5 percent to the Japanese yen for the period January 1993 to January 2003. Qzum (2007) empirically examined the impacts of the volatility in the time value of the US dollar on the returns of the world stock markets.

\section{The proposed study}

This paper presents an empirical investigation to study the effects of different factors influencing on profitability of shares of petrochemical industry. The study gathers the information of three firms whose stock price was listed on Tehran Stock Exchange over the period 2006-2012. The proposed study considers the following variables for the proposed study,

1. Earnings per share (EPS): Earnings per share is one of the most important financial factors considered by managers, investors and financial analysts and it is often used for measuring the profitability, risk assessment and investment decisions.

2. Price per share: In this study, we consider closing price of the trading share, which is calculated seasonally.

3. Currency exchange: Currency exchange is another important variable in this study, which is calculated seasonally.

4. Material: This item in petrochemical industry includes natural gas liquids, liquefied natural gas, sweet gas, sour gas, rich gas, natural gas, ethane, naphtha and condensate oil. 
5. Energy price: Important energy components include gasoline, diesel, kerosene, fuel oil, electricity, natural gas and liquefied petroleum gas, which are the major energy consumption. In this study, this item is calculated as the ratio of cost of fuel and energy divided by the cost of goods and services.

6. Liquidity: A measure of the extent to which a person or organization has cash to meet immediate and short-term obligations, or assets that can be quickly converted to do this. In this study, we use macro-economic figures (Vakil Alroaia et al., 2014).

7. Gold price: Gold price is one of the most important hedges in economy and this study considers this factor as part of the survey.

The proposed study of this paper considers the following six hypotheses:

1. There is a relationship between EPS and stock price.

2. There is a relationship between EPS and currency exchange.

3. There is a relationship between EPS and materials used in petrochemical industry.

4. There is a relationship between EPS and energy prices.

5. There is a relationship between EPS and liquidity.

6. There is a relationship between EPS and gold price.

To examine different hypotheses of the survey, the study uses the following regression function,

Profit $=\alpha_{0}+\alpha_{1}$ Price $+\alpha_{2}$ Ex-change $+\alpha_{3}$ Material $+\alpha_{4}$ Energy $+\alpha_{5}$ Liquid $+\alpha_{6}$ Market $+\varepsilon$

where Profit is the dependent variable, which is associated with earnings per share. In addition, Price, Ex-change, Material, Energy, Liquid and Market represent stock price, currency exchange, raw materials used in petrochemical industry, energy, liquidity and gold price, respectively. Moreover, $\alpha_{0}$ to $\alpha_{6}$ represent coefficients to be estimated and finally $\varepsilon$ represents residuals. Table 1 shows details of some basic statistics on dependent and independent variables. In addition, Table 2 demonstrates the results of Kolmogorov-Smirnov test.

\section{Table 1}

The summary of some basic statistics

\begin{tabular}{lccccccc}
\hline Variable & Price & Currency & Material & Energy & Liquidity & Gold & EPS \\
\hline Number & 84 & 84 & 84 & 84 & 84 & 84 & 84 \\
Mean & 7431.768 & 11112.93 & 666.0185 & 0.417 & $2.37 \mathrm{E}+15$ & $1.34 \mathrm{E}+07$ & 1075.536 \\
Standard deviation & 667.3812 & 426.8526 & 90.02094 & 0.00666 & $1.11 \mathrm{E}+14$ & $9.98 \mathrm{E}+05$ & 145.7886 \\
Median & 5281.015 & 9946 & 253.5 & 0.01 & $2.14 \mathrm{E}+15$ & $1.02 \mathrm{E}+07$ & 576.5 \\
Mode & 920.02 & 12260 & 165 & 0 & $9.61 \mathrm{E}+14$ & 5662925 & $-23.00^{\mathrm{a}}$ \\
Standard deviation & 6116.649 & 3912.168 & 825.0555 & 0.06107 & $1.02 \mathrm{E}+15$ & $9.15 \mathrm{E}+06$ & 1336.175 \\
Variance & $3.74 \mathrm{E}+07$ & $1.53 \mathrm{E}+07$ & 680716.6 & 0.004 & $1.04 \mathrm{E}+30$ & $8.37 \mathrm{E}+13$ & 1785362 \\
Skewness & 0.696 & 3.111 & 1.693 & 1.687 & 0.585 & 2.061 & 2.061 \\
Kurtosis & -0.716 & 8.497 & 1.6 & 1.806 & -0.682 & 4.142 & 4.899 \\
Rang & 21905.14 & 15888 & 2660 & 0.22 & $3.65 \mathrm{E}+15$ & 37345505 & 6914 \\
Min & 578.9 & 9133 & 40 & 0 & $9.61 \mathrm{E}+14$ & 5662925 & -79 \\
Max & 22484.04 & 25021 & 2700 & 0.22 & $4.61 \mathrm{E}+15$ & 43008430 & 6835 \\
\hline
\end{tabular}


Table 2

The summary of Kolmogorov-Smirnov test

\begin{tabular}{cccccc}
\hline Variable & Number & KZ & P-Value & Significance level & Result \\
\hline Price & 84 & 1.45 & 0.03 & 0.05 & Not confirmed \\
Exchange & 84 & 3.237 & 0.000 & 0.05 & Not confirmed \\
Material & 84 & 2.628 & 0.000 & 0.05 & Not confirmed \\
Energy & 84 & 2.58 & 0.000 & 0.05 & Not confirmed \\
Liquid & 84 & 1.246 & 0.9 & 0.05 & Confirmed \\
Market & 84 & 1.833 & 0.002 & 0.05 & Not confirmed \\
\hline
\end{tabular}

As we can observe from the results of Table 2, most of the variables are not normally distributed and we therefore have to make some changes on variables to convert them into normally distributed variables. In this study, we use Tprice $=\ln ($ Price), Texchange $=\operatorname{COS}($ Exchange), Tmaterial $=$ $(\text { Material })^{-0.25}$, Tenergy $=(\text { Energy })^{0.5}$, Tmarket $=\ln ($ Market $)$ and TEPS $=\ln ($ EPS +80$)$. Table 3 shows details of Pearson correlation ratios among different variables.

Table 3

The summary of Pearson correlation

\begin{tabular}{|c|c|c|c|c|c|c|c|c|}
\hline Variable & & EPS & Price & Exchange & Material & Energy & Liquid & Market \\
\hline \multirow{2}{*}{ EPS } & $r$ & 1 & & & & & & \\
\hline & $\mathrm{P}$-value & & & & & & & \\
\hline \multirow{2}{*}{ Price } & $r$ & $.766^{* *}$ & 1 & & & & & \\
\hline & $\mathrm{P}$-value & 0.000 & & & & & & \\
\hline \multirow{2}{*}{ Exchange } & $r$ & $.444^{* *}$ & 0.206 & 1 & & & & \\
\hline & P-value & 0 & 0.06 & & & & & \\
\hline \multirow{2}{*}{ Material } & $\bar{r}$ & $.312^{* \pi}$ & 0.202 & $.541^{* *}$ & 1 & & & \\
\hline & $\mathrm{P}$-value & 0.004 & 0.065 & 0 & & & & \\
\hline \multirow{2}{*}{ Energy } & $\mathrm{r}$ & $-.352^{* *}$ & $-.499^{* *}$ & 0.202 & -0.109 & 1 & & \\
\hline & P-value & 0.001 & 0 & 0.065 & 0.326 & & & \\
\hline \multirow{2}{*}{ Liquid } & $\mathrm{r}$ & $.340^{* *}$ & 0.144 & $.730^{* * *}$ & $.736^{* *}$ & $.318^{* *}$ & 1 & \\
\hline & P-value & 0.002 & 0.192 & 0 & 0 & 0.003 & & \\
\hline \multirow{2}{*}{ Market } & $\mathrm{r}$ & $.422^{* *}$ & 0.197 & $.945^{* *}$ & $.679^{* * *}$ & $.276^{*}$ & $.901^{* *}$ & 1 \\
\hline & P-value & 0 & 0.072 & 0 & 0 & 0.011 & 0 & \\
\hline
\end{tabular}

As we can observe from the results of Table 3, there are some positive and strong correlations between dependent variable and independent variables. Next, we present details of our findings on testing various hypotheses of the survey.

\section{The results}

As mentioned earlier, the study has made some changes on the data and uses the following model to do the regression model,

Eps $=\beta_{0}+\beta_{1}$ TPrice $+\beta_{2}$ Texchange $+\beta_{3}$ TMaterial $+\beta_{4}$ Tenergy $+\beta_{5}$ Liquid $+\beta_{6}$ TMarket $+\varepsilon$

Table 4 demonstrates the results of regression analysis. We have also used stepwise regression technique and the results are stated in Eq. (3).

\section{Table 4}

The summary of regression analysis

\begin{tabular}{llccccc}
\hline Variable & & Coefficient & Standard deviation & t-value & P-value & Result \\
\hline & $\beta_{0}$ & -5.149 & 12.778 & -0.403 & 0.688 & \\
Tprice & $\beta_{1}$ & 0.951 & 0.141 & 6.763 & 0.000 & Confirmed \\
Texchange & $\beta_{2}$ & -0.306 & 0.147 & -2.086 & 0.04 & Confirmed \\
Tmaterial & $\beta_{3}$ & -2.138 & 2.721 & -0.786 & 0.434 & Not Confirmed \\
Tenergy & $\beta_{4}$ & -0.624 & 1.007 & -0.62 & 0.537 & Not Confirmed \\
Liquid & $\beta_{5}$ & $3.55 E-17$ & 0.000 & 0.072 & 0.943 & Not Confirmed \\
Tmarket & $\beta_{6}$ & 0.243 & 0.85 & 0.286 & 0.776 & Not Confirmed \\
\hline
\end{tabular}


As we can observe from the results of Table 4, the effects of stock price and exchange rate have been confirmed but the effects of other four variables have not been confirmed.

TPROFIT $=-1.000+0.981$ TPRICE -0.312 TExchange -4.042 TMaterial $+\varepsilon$

The results of regression analysis given in Eq. (3) show that the effects of stock price, currency exchange and materials are meaningful but the other three variables; namely, energy, liquidity and gold do not represent meaningful impact on EPS.

\section{Conclusion}

In this paper, we have studied the effects of different factors on earnings of some selected petrochemical firms listed on Tehran Stock Exchange. The results of our investigation have confirmed that while stock price, currency exchange and raw materials could influence on earnings per share, energy, liquidity and gold did not represent meaningful impact on EPS.

\section{Acknowledgement}

The authors would like to thank the anonymous referees for constructive comments on earlier version of this paper.

\section{References}

Azad, N \& Mohajeri, L. (2002). The effects of intellectual capital on financial performance: A case study of petrochemical and pharmaceutical firms. Management Science Letters, 2(2), 511-516.

Bernotas, D. (2005). Ownership structure and firm profitability in the Japanese keiretsu. Journal of Asian Economics, 16(3), 533-554.

Dechow, P. M. (1994). Accounting earnings and cash flows as measures of firm performance: The role of accounting accruals. Journal of Accounting and Economics, 18(1), 3-42.

Farzinfar, A. (2012). A study on the relationship between intellectual capital, earning per share and income growth: A case study of Tehran Stock Exchange. Management Science Letters, 2(8), 27652776.

Feeny, S. (2000). Determinants of profitability: an empirical investigation using Australian tax entities. Melbourne Institute of Applied Economic and Social Research.

Ghodrati, H., Jabbari, H \& Esfandyari, M. (2014). A study on relationship between assets' objectivity, ROA, ROE and ownership ratio with liquidity cycle. Management Science Letters, 4(6), 1341-1352.

Khaksarian, F. (2014). A study on the effect of working capital management on profitability on Cement and Petrochemical industries: Evidence from Tehran Stock Exchange. Management Science Letters, 4(7), 1571-1576.

Madsen, J. B. (2002). Share returns and the Fisher hypothesis reconsidered. Applied Financial Economics, 12(8), 565-574.

Muller, A., \& Verschoor, W. F. (2007). Asian foreign exchange risk exposure. Journal of the Japanese and International Economies, 21(1), 16-37.

Ozum, A. (2007). International Transmission of Volatility in the US Interest Rates into the Stock Returns: Some Comparative Evidence from World Equity Markets. International Research Journal of Finance and Economics, 10.

Patell, J. M. (1976). Corporate forecasts of earnings per share and stock price behavior: Empirical test. Journal of Accounting Research, 14(2), 246-276.

Saaty, T. L. (1990). An exposition of the AHP in reply to the paper "remarks on the analytic hierarchy process". Management science, 36(3), 259-268.

Saaty, T. L. (1994). Fundamentals of decision making. Pittsburgh: RWS Publications. 
Saaty, T. L. (2003). Decision-making with the AHP: Why is the principal eigenvector necessary. European journal of operational research, 145(1), 85-91.

Shaverdi, M., Heshmati, M. R., \& Ramezani, I. (2014). Application of Fuzzy AHP Approach for Financial Performance Evaluation of Iranian Petrochemical Sector.Procedia Computer Science, 31, 995-1004.

Stern, J. M. (1974). Earnings per share is a poor indicator of performance. Omega, 2(1), 11-32.

Tursoy, T., Gunsel, N., \& Rjoub, H. (2008). Macroeconomic factors, the APT and the Istanbul Stock Market. International Research Journal of Finance and Economics, 22, 49-57.

Vakil Alroaia, Y., Makrani, K \& Banagozar, A. (2014). Investigating the effects of liquidity and exchange rate on Tehran Stock Exchange. Management Science Letters, 4(8), 1865-1870. 